\title{
Trends of land cover change in a key biological corridor in Central Nepal
}

\author{
KRIPA NEUPANE ${ }^{1, \bullet}$, AMBIKA P. GAUTAM ${ }^{1}$, ARUN REGMI ${ }^{2}$ \\ ${ }^{1}$ Kathmandu Forestry College, Tribhuvan University. Kathmandu, Nepal. "email: nr.kripa@gmail.com \\ ${ }^{2}$ Department of Forestry, Mississippi State University. Starkville, MS, USA \\ Manuscript received: 20 November 2017. Revision accepted: 3 December 2017.
}

\begin{abstract}
Neupane K, Gautam AP, Regmi A. 2017. Trends of land cover change in a key biological corridor in Central Nepal. Asian J For 1: 64-69. Monitoring changes in biophysical features of the earth is useful to assess the impacts of human activities on the environment. This effort is essential to evaluate, for example, the outcome of policy implementation. This study analyzed changes in land cover in one of the key biological corridors in Central Nepal, the Barandabhar Corridor located in Chitwan District, during the last two decades (i.e. 1991 to 2013). The study used satellite imageries (Landsat 5 TM of 1991 and Landsat 8 OLI_TIRS of 2013) and the results were cross-checked with primary data collected from the field to investigate the drivers of land cover change. Supervised Maximum Likelihood method of image classification was used to produce the land cover maps for 1991 and 2013. The result showed that forest cover in the corridor increased by $7.03 \%$ while the coverage of shrubland, water bodies and other land cover types (open lands, sand and roads) decreased during the study period. The implementation of community-based forest management programs, decreasing dependency of local communities on forest resources, and increasing awareness in conservation among the local people are found to be the main causes of the increase in forest cover.
\end{abstract}

Keywords: Barandabhar corridor, Land cover change, Landsat, Nepal, Supervised classification

\section{INTRODUCTION}

Several regions around the world are facing land cover change at an alarming rate. The concern on this issue has increased research on global environmental change (Lambin et al. 2003). Land cover change analysis has been recognized as a key proxy for identifying the impact of change on the environment and associated ecosystems (Turner et al. 1995; William et al. 1994). Land cover change occurs because of human activities and/or natural processes. Land use practices, such as agricultural expansion, infrastructure developments, deforestation and encroachment, have the largest impact on land cover change (Lambin et al. 2003). In addition, population growth (Geist and Lambin 2002) and climate change (Fischlin and Midgley 2007) are also considered as other major driving forces of land cover change.

Remote sensing and Geographic Information Systems (GIS) are the most feasible and efficient tools to monitor land cover change, both spatially and temporally (Lambin et al. 2003; Serra et al. 2008). Satellite imageries have been widely used to detect physical features and natural resource dynamics over time (Balla et al. 2007) along with the visual assessment that occurs at a particular time and place (Awasthi 2004). Analysis of satellite images of the same area taken at different times is a widely used method for determining the temporal dynamics of land use (Mulders 2001).

Since the past two decades, the trends in using satellite remote sensing data to detect earth features have been considerably increasing in Nepal (Sharma 2002). For example, several studies (e.g., Balla et al. 2000; Gardner and Gerrard 2001; Gautam et al. 2003) have been carried out to analyze land use and land cover change, deforestation, and forest degradation using remote sensing data.

The Barandabhar Corridor is the only remaining natural forest that connects the Chitwan National Park (CNP) and Siwalik Range with the Mahabharat Range (Dhakal and Yadava 2011). The existence of this corridor is important to facilitate the endangered one-horned rhinoceros (Rhinoceros unicornis), Royal Bengal tiger (Panthera tigris tigris), and many other species of wild animals and birds to move to refuge areas at higher altitudes during monsoon floods (Tiwari et al. 2007) and other periods of adverse climatic conditions. Approximately $75 \%$ of Barandabhar corridor was previously forested with a rich diversity of flora and fauna (Joshi 2002; Bennett 2004). However, the anthropocentric pressures on Barandabhar Corridor have increased substantially (Thakur 2012), resulting in deforestation, destruction of natural habitats and conversion of the forested area into agricultural land (Shrestha 2001).

Studies of land cover change in Barandabhar Corridor are lacking and such studies only focused on investigating deforestation and forest degradation (Panta et al. 2008; WWF 2013), and few others were done in floral diversity (Subedi, 1994; Dangol and Shivakoti 2001; Shrestha 2003). Therefore, the present study aims to assess land cover changes in Barandabhar Corridor in the past two decades (1991-2013) along with the driving forces of such changes. 


\section{MATERIALS AND METHODS}

\section{Study area}

The Barandabhar Corridor is located within the Terai Arc Landscape of Nepal between Chitwan National Park (CNP) and the Mahabharat Range. It has coordinates of $27^{\circ} 33^{\prime} 30^{\prime \prime}$ to $27^{\circ} 44^{\prime} 30^{\prime \prime} \mathrm{N}$ Latitude and $84^{\circ} 22^{\prime} 30^{\prime \prime}$ to $84^{\circ} 34^{\prime} 00^{\prime \prime E}$ Longitude (Figure 1) and covers 11,155.77 hectares (ha). The elevation ranges from $172 \mathrm{~m}$ to $390 \mathrm{~m}$ above sea level. The climate is subtropical with distinct winter (November-February), spring (May-September) and monsoon (June-September) seasons. The average annual rainfall is $2000 \mathrm{~mm}$ during the monsoon season. Rapti, Budhi-Rapti, and Khageri are the main rivers that flow through the forest. A Ramsar-enlisted wetland called the Bishazari Tal, lies in the center of the forest.

The Corridor is divided by the East-West Highway into two parts. The northern part covers an area of 3,184 ha, which is managed by 15 community forestry user groups (Aryal et al. 2012). The southern part has been declared as the buffer zone of CNP and is managed by six buffer zone community forest user groups (CNP 2013). Sal (Shorea robusta) is the dominant tree species throughout the corridor forest. Riverine, tall grassland and short grassland occupy part of the corridor area. The area is a key habitat for some endangered species, including the Royal Bengal tiger (Panthera tigris tigris) and one-horned rhino (Rhinoceros unicornis) (CNP 2013).
Agriculture represents the main source of livelihood of the local people (CBS 2012). The local inhabitants comprise many ethnic groups, including Brahmin, Chhetri, Tharus, and other ethnic groups. Most of the people are migrated to this area from the hilly regions of Nepal.

\section{Data collection}

Two types of satellite imageries, namely Landsat 5 TM of 1991 and Landsat 8 OLI_TIRS of 2013, were used for the detection of changes in land cover during the study period. These images were downloaded free of cost from the Earth Resource Observation System Data Centre of the USGS (http: //www.glovis.usgs.gov). A brief description of the satellite images used is shown in Table 1. Topographic map of the scale 1: 25,000, which was acquired from the Department of Survey, Government of Nepal, was digitized to create a spatial database and classify 1991 TM image. Data of the different land cover classes obtained from field study (GPS location) was used as training samples.

Non-spatial data were collected through the questionnaire survey, key informant interviews, focus group discussions, and direct field observations in order to identify the major driving forces responsible for the land cover changes. A total of 80 households around the forest corridor were selected using a stratified random sampling method for the questionnaire survey. Focus group discussion was conducted with different communities and user groups.

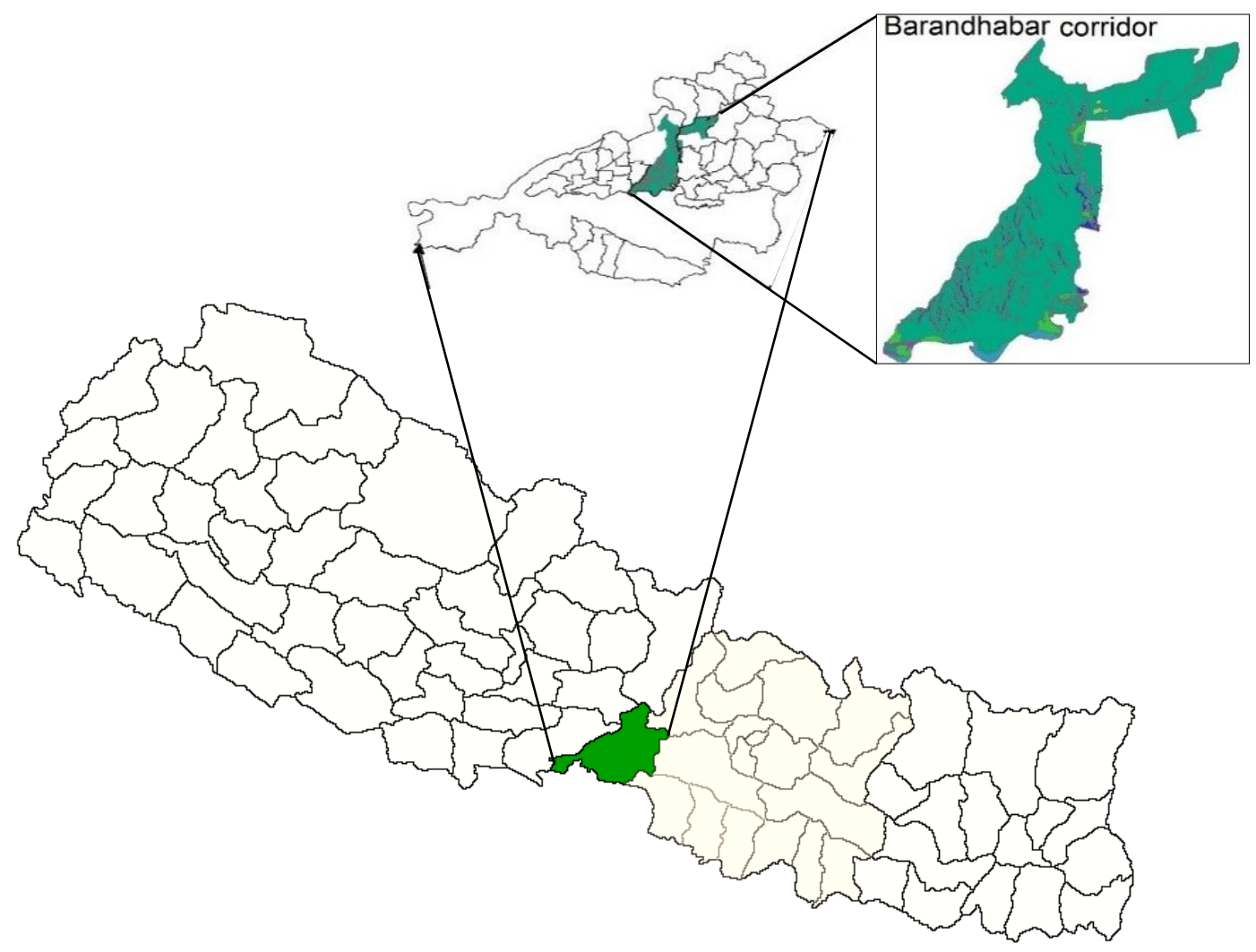

Figure 1. Map of the study area in the Barandabhar Corridor, Chitwan District, Nepal 
Table 1. Satellite images used in land cover classification

\begin{tabular}{llccl}
\hline $\begin{array}{l}\text { Satellite } \\
\text { image }\end{array}$ & Sensor & $\begin{array}{c}\text { Number } \\
\text { of } \\
\text { bands }\end{array}$ & $\begin{array}{c}\text { Spatial } \\
\text { resolution } \\
\text { (meter) }\end{array}$ & $\begin{array}{l}\text { Date of } \\
\text { acquisition }\end{array}$ \\
\hline Landsat 5 & TM & $1-7$ & $30 * 30$ & $1991-10-12$ \\
Landsat 8 & OLI_TIRS & $1-11$ & $30 * 30$ & $2013-11-18$ \\
\hline
\end{tabular}

In addition, local government forestry officials, CFUG's and BZCFUG's committee members, and environmental NGOs were also consulted. Secondary data and information were obtained from governmental offices, CNP, DNPWC, literature review, research articles and internet browsing.

\section{Data analysis}

The analyses of the remote sensing data were carried out in ArcGIS, and ERDAS Imagine environments. Images were extracted from the same source and already orthorectified, so rectification was not needed (ERDAS 2002). Images were reprojected to the UTM $44 \mathrm{~N}$ by using nearest neighborhood re-sampling. Area of Interest (AOI) was separated by using subset tool of ERDAS Imagine to match the satellite image for the topo-sheet compatible. The digitized map was re-projected to UTM/WGS 84, Zone 44 $\mathrm{N}$ to match with satellite images.

Maximum likelihood algorithm of supervised classification method was used for the classification of two imageries. GPS locations corresponding to each Land Use and Land Cover (LULC) class were collected from the field and used as training samples for the image classification and accuracy assessment. Four land cover classes were considered in image classification to produce land cover maps and to detect changes that occurred during the period 1991-2013: (i) forest, (ii) shrubland, (iii) water bodies, iv) others (open lands, sand, and roads). Description of these land cover classes is presented in Table 2. The digitized topographic map was used to classify 1991 TM image whereas 2013 OLI_TIRS image was classified based on training samples collected during the field visit.

Land cover changes were calculated using raster calculator tool in Arc GIS. Similarly, quantitative and qualitative data were analyzed by using descriptive statistical tools such as frequency, percentage and mean in SPSS and MS-Excel software.

\section{Accuracy assessment}

Error matrix, the most common way to present accuracy of the classified digital image (Fan et al. 2007), was used for assessing the accuracy of classified images. The overall accuracy of the 1991 image classification was $88.5 \%$ with Kappa coefficient of $84.6 \%$, and that of the 2013 image was $92.78 \%$ with Kappa coefficient of $90.3 \%$.

\section{RESULTS AND DISCUSSION}

\section{Change in land use and land cover of Barandabhar Corridor during 1991-2013}

By comparing land cover maps of 1991 and 2013, it is found that forest area has increased by $7.03 \%$, whereas the coverage of shrubland, water bodies and other land cover types (open lands, sand and roads) decreased by $2.88 \%$, $0.59 \%$, and $3.55 \%$ respectively. The forest cover was 7,650 ha $(68.57 \%)$ in 1991 , which increased at the rate of $0.44 \%$ per year to 8433.72 ha $(75.60 \%)$ in 2013 . Shrubland, water bodies and other land cover types (open lands, sand and roads) have decreased by 321.75 ha, 65.43 ha, and 396.54 ha respectively, at the rate of $0.86 \%, 1.5 \%$ and $1.48 \%$ per year. Net forest gain during this period was 783.72 ha $(7.03 \%)$ (Table 3; Figure 2-5). A similar trend was observed in the previous land use and land cover (LULC) studies conducted in different locations across Nepal, e.g., (Gautam et al. 2003; Balla et al. 2007; Pokhrel and Shah 2008).

Table 2. Categories of land cover classes considered in the analysis

\begin{tabular}{ll}
\hline Land cover class & Description \\
\hline Forest & Area covered by trees, poles, and saplings of different species \\
Shrubland & Area consisting of shrubs, bushes and young regeneration of tree species. \\
Water bodies & Lake, river \\
Others & Areas with no vegetation cover, stony areas, open lands, sand, roads \\
\hline
\end{tabular}

Table 3. Land covers changes in Barandabhar Corridor, Chitwan District, Nepal between 1991-2013

\begin{tabular}{|c|c|c|c|c|c|c|c|}
\hline \multirow{2}{*}{ Land cover class } & \multicolumn{2}{|c|}{2013} & \multicolumn{2}{|c|}{1991} & \multicolumn{2}{|c|}{ Change } & \multirow{2}{*}{$\begin{array}{c}\text { Rate of Change } \\
(\%)\end{array}$} \\
\hline & Area (ha) & $\%$ cover & Area (ha) & $\%$ cover & Area (ha) & \% Cover & \\
\hline Forest & $8,433.7$ & 75.6 & 7,650 & 68.5 & 783.7 & 7.0 & 0.4 \\
\hline Shrubland & $1,534.9$ & 13.7 & $1,856.7$ & 16.6 & -321.7 & -2.8 & -0.8 \\
\hline Water bodies & 166.4 & 1.4 & 231.8 & 2.0 & -65.4 & -0.5 & -1.5 \\
\hline Others & $1,020.6$ & 9.1 & $1,417.2$ & 12.7 & -396.5 & -3.5 & -1.4 \\
\hline Total & $11,155.7$ & 100 & $11,155.7$ & 100 & & & \\
\hline
\end{tabular}




\section{Factors contributing to the changes in land cover}

The implementation of the Community Forestry $(\mathrm{CF})$ and Buffer Zone Community Forestry (BZCF) programs are found to be the major direct drivers responsible for the increase in forest cover in the corridor. Effective law enforcement in the BZCF by the Chitwan National Park office and conservation of their respective forest blocks by the local community forest user groups led to increase in the forest area. Decreased dependency of the local people on forest products, such as fuelwood, timber, and fodder, due to easy availability of alternatives, like LP gas, kerosene, fuel oil, biogas, improved cooking stoves, etc., alongside improved economic well-being of the people living around the corridor has reduced the biotic pressure on the corridor forest, contributing to forest cover increase.

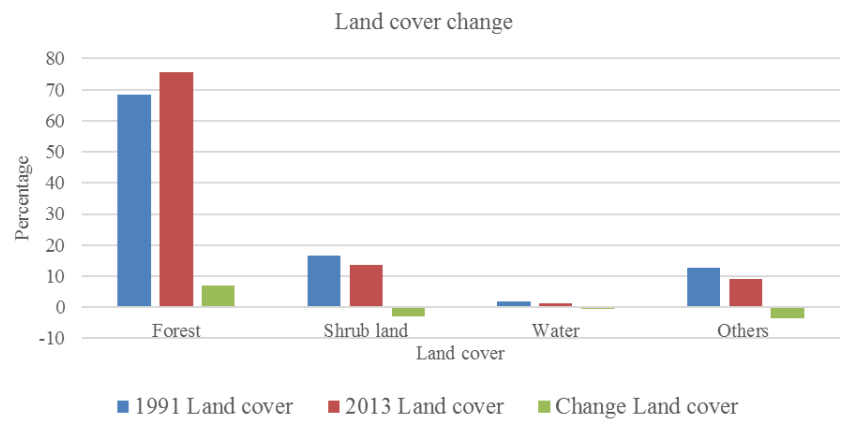

Figure 2. Land cover change during 1991 and 2013 in the Barandabhar Corridor, Chitwan District, Nepal

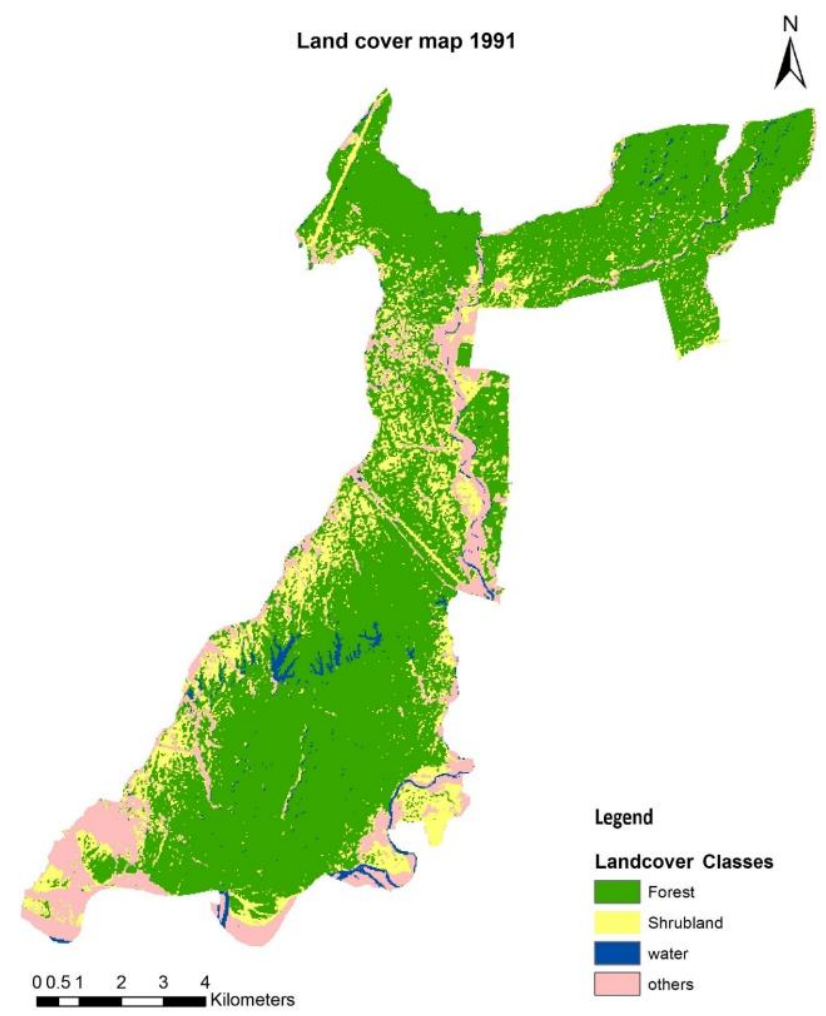

Figure 3. Land cover of the Barandabhar Corridor, Chitwan District, Nepal in 1991

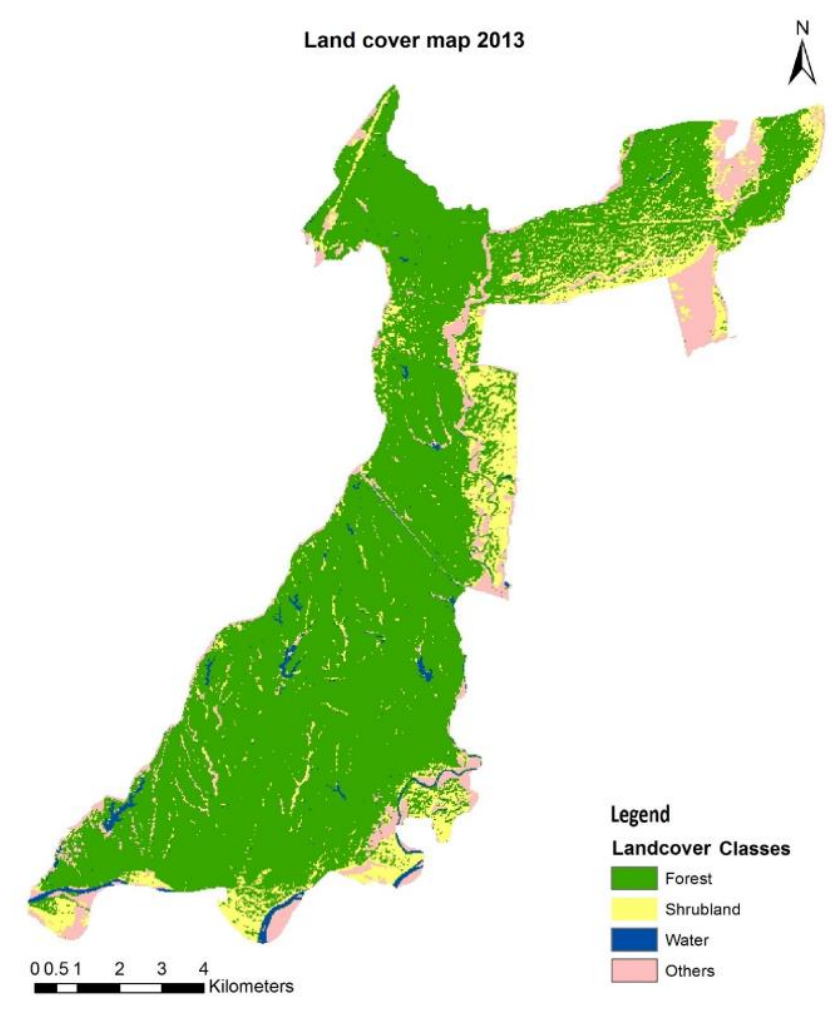

Figure 4. Land cover of the Barandabhar Corridor, Chitwan District, Nepal in 2013

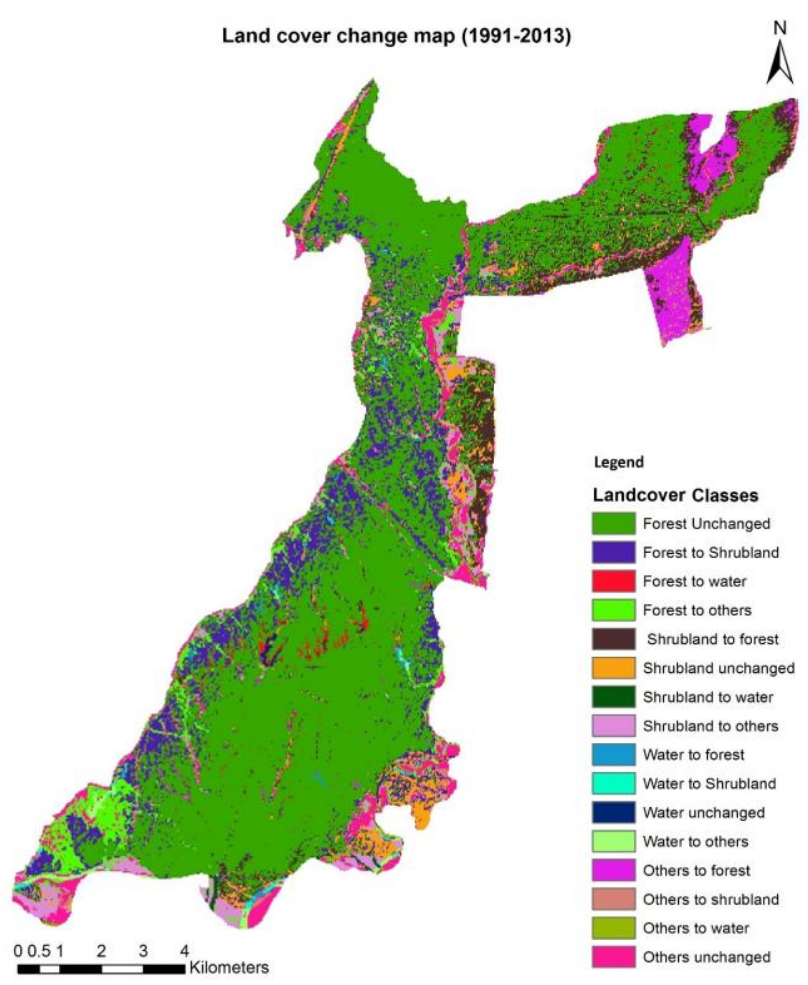

Figure 5. Land cover change map (1991-2013) of the Barandabhar Corridor, Chitwan District, Nepal 
Furthermore, the control in grazing by the CFUGs and the decrease in the number of livestock and fodder demand from forest due to the promotion of stall-feeding also have had a positive impact on vegetative cover. Plantation establishment by the Department of Forests, FUGs, and BZFUGs on degraded forestlands, barren lands, and grasslands with external assistance has contributed to the forest cover increase. Various national and international organizations (such as NTNC, WWF Nepal) are also involved in the conservation and management of the corridor. Currently, the Corridors and Bottlenecks Restoration Project (CBRP) and Protected Area and Buffer Zone (PABZ) projects are being implemented under TAL program. Increasing awareness among local people about the ecological benefits of protecting and sustainably managing forests also has had a positive impact on the forest cover change.

Invasion by alien plant species has been found to be an important driving agent for decrease in the area of lakes. The Ramsar-enlisted Bishazari Lake is infested with invasive alien plants such as Eichhornia crassipes (water hyacinth), Pistia stratiotes (water lettuce), Alternanthera philoxeroides (alligator weed), Ipomoea carnea (bush morning glory), Ageratina adenophora (Crofton weed), and Leersia hexandra (southern cut grass). Sedimentation is found to be another factor responsible for reducing lake surface area. Change in the course of flow by Rapti River has resulted in the conversion of riverbeds into grassland. Construction of East-west Mahendra Highway within the forest land, new towns, high voltage electric transmission lines around the forest corridor, and the newly constructed road connecting from new Padampur to Bhojad by VDC also have a direct contribution towards land cover change throughout the study area.

The findings of this study are similar to previous studies conducted in different parts of Nepal in recent years. For example, the forest cover change analysis carried out in 20 districts of Nepal during 1990/91 to 2000/2001 by the Department of Forests showed that forest cover increased at annual rate of $0.06 \%$ during the period (DoF 2005). In the study of land cover change in watershed level, Gautam et al. (2003) found increase in forest cover mainly due to the conversion of shrublands into forests after implementation of the community forestry program.

\section{Conclusions}

The study analyzed the trends of changes in land cover of Barandabhar Corridor using Landsat satellite images and GIS. The results show that forest area is the major land cover and has increased by the rate of $0.44 \%$ per annum during the period 1991-2013. On the contrary, shrubland, water bodies and other land cover types (open lands, sand and roads) have decreased by the rate of $0.86 \%, 1.5 \%$ and $1.48 \%$ per annum respectively. The findings of this study indicate that successful implementation of communitybased forest management (CBFM) programs have contributed positively toward restoring the forest cover in the corridor.

Formation of community forest, active participation of CFUGs, the involvement of different national and international organizations for the conservation and management of corridors and low dependency on forest resources are the major drivers of increasing forest cover. Control of illegal felling and grazing, protection of severely degraded forest land, and plantation in the barren land have increased forest regeneration, resulting in dense forest cover. On the other hand, expansion of invasive alien plant species, sedimentation, changes in the flow of Rapti River, infrastructure development are found to be the major drivers for decreasing shrubland, water bodies and other land cover types (open lands, sand, and roads). The positive impact of community-based institutions in improving forest cover in the study area provides an important basis for implementing community-based strategies in the management of protected area buffer zones and biological corridors in other locations in Nepal and other countries with similar socio-economic and ecological contexts.

\section{ACKNOWLEDGEMENTS}

We would like to express our profound thankfulness and appreciation to World Wildlife Fund (WWF), Hariyo Ban Small grant program, Nepal for granting us financial support for this research work.

\section{REFERENCES}

Aryal A, Brunton D, Pandit, et al. 2012. Biological diversity and management regimes of the northern Barandabhar Forest Corridor: an essential habitat for ecological connectivity in Nepal. Trop Conserv Sci 5 (1): 38-49. DOI: 10.1177/194008291200500105

Awasthi K. 2004. Land-use change effects on soil degradation, carbon and nutrient stocks and greenhouse gas emission in mountain watersheds: Department of Plant and Environmental Sciences, Agricultural University of Norway, Oslo.

Balla M, Awasthi K, Shrestha P, Sherchan D, Poudel D. 2000. Degraded Lands in Mid-hills of Central Nepal: A GIS appraisal in quantifying and planning for sustainable rehabilitation. LI-BIRD, Pokhara, Nepal

Balla M, Awasthi K, Singh B, Sitaula B, Pradhan B. 2007. Land Use Changes and Geomorphometric Analyses in Galaundu and Pokhare Khola Watersheds in Mid-hill Region of Nepal. Intl J Ecol Environ Sci 33 (2-3): 171-182.

Bennett G. 2004. Integrating Biodiversity Conservation and Sustainable Use: Lessons Learned from Ecological Networks. IUCN, Gland.

CBS. 2012. National population and housing census 2011 National Report. Central Bureau of Statistics National Planning Commission Secretariat, Government of Nepal, Kathmandu, Nepal.

CNP. 2013. Management Plan for Chitwan National Park and It's Buffer Zone 2013-2017. Chitwan National Park Office, Chitwan, Nepal.

Dangol D, Shivakoti G. 2001. Species composition and dominance of plant communities in western Chitwan, Nepal. Nepal Journal of Science and Technology 3 (1): 69-78.

DFRS/FRA. 2014. Terai Forests of Nepal (2010-2012). Forest Resource Assessment Nepal Project/Department of Forest Research and Survey, Babarmahal, Kathmandu.

Dhakal RR, Yadava JN. 2011. Comparative assessment of floristic diversity in a buffer zone community forest and a community forest of Barandabhar corridor, Chitwan, Nepal. J Hortic For 3 (8): 244-250.

DoF. 2005. Forest Cover Change Analysis of the Terai Districts 1990/912000/01. Department of Forests (DoF), Kathmandu, Nepal.

ERDAS L. 2002. ERDAS Imagine Field Guide. Erdas Inc., Atlanta, Georgia.

Fan F, Weng Q, Wang Y. 2007. Land use and land cover change in Guangzhou, China, from 1998 to 2003, based on Landsat TM/ETM+ imagery. Sensors 7 (7): 1323-1342. 
Fischlin A, Midgley G. 2007. Ecosystems, their properties, goods and services. In: IPCC, climate change 2007-the working group II contribution to the IPCC fourth assessment report. Cambridge University Press, Cambridge

Gardner R, Gerrard J. 2001. Soil loss on noncultivated land in the Middle Hills of Nepal. Physic Geogr 22 (5): 376-393. DOI 10.1080/02723646.2001.10642750

Gautam AP, Webb EL, Shivakoti GP, Zoebisch MA. 2003. Land use dynamics and landscape change pattern in a mountain watershed in Nepal. Agric Ecosys Environ 99 (1): 83-96. DOI: 10.1016/S01678809(03)00148-8

Geist HJ, Lambin EF. 2002. Proximate causes and underlying driving forces of tropical deforestation: Tropical forests are disappearing as the result of many pressures, both local and regional, acting in various combinations in different geographical locations. BioScience 52 (2): $143-150$ DOI: 3568(2002)052[0143:PCAUDF]2.0.CO;2

Joshi A. 2002. Establishing Biological Monitoring System for Terai Arc Landscape. World Wildlife Fund (WWF) Nepal Program. Kathmandu, Nepal

Lambin EF, Geist HJ, Lepers E. 2003. Dynamics of land-use and landcover change in tropical regions. Ann Rev Environ Resour 28 (1): 205-241. DOI: 10.1146/annurev.energy.28.050302.105459

Mulders MA. 2001. Advances in the application of remote sensing and GIS for surveying mountainous land. Intl J Appl Earth Observ Geoinform 3 (1): 3-10. DOI: 10.1016/S0303-2434(01)85015-7

Panta M, Kim K, Joshi C. 2008. Temporal mapping of deforestation and forest degradation in Nepal: applications to forest conservation. For Ecol Manag 256 (9): 1587-1595. DOI: 10.1016/j.foreco.2008.07.023

Pokhrel GK, Shah KB. 2008. Role of community forests in faunal diversity conservation: a case study of community forests within Satbariya Range Post of Dang District. Nepal J Sci Technol 9: 111117. DOI: $10.3126 /$ njst.v9i0.3174
Serra P, Pons X, Saurı' D. 2008. Land-cover and land-use change in a Mediterranean landscape: a spatial analysis of driving forces integrating biophysical and human factors. Appl Geogr 28: 189-209. DOI: $10.1016 /$ j.apgeog.2008.02.001

Sharma RR. 2002. Monitoring Forest Resources Using Remote Sensing Data. www.gisdevelopment.net/aars/acrs/2002/for/167.pdf [September 2015]

Shrestha B. 2003. Phytoecology of Barandabhar Forest, Chitwan, Nepal. [Thesis]. Central Department of Botany, Tribhuvan University, Kathmandu, Nepal.

Shrestha N. 2001. The political economy of land, landlessness and migration in Nepal. Nirala, New Delhi.

Subedi M. 1994. Structure, composition and general characteristics of some major forest types surveyed on natural and semi-natural forest stand in Nepal Proceeding of II National Conference on Science and Technology, Kathmandu.

Thakur R. B. 2012. Assessment of the land use land cover change in the forest corridor of Lamahi bottleneck area of Terai Arc Landscape Nepal. [Thesis]. Department of Natural Resources, TERI University, New Delhi.

Tiwari S, Regmi R, Green M. 2007. Tiger-rhino conservation project: landscape-scale conservation of the endangered tiger and rhino population in and around Chitwan National Park. Report of the final evaluation mission. United Nations Development Programme, UK.

Turner II BL, Skole D, Sanderson S, Fischer G, Fresco L, Leemans R. 1995. Land-Use and Land-Cover Change Science/Research Plan. IGBP Report No. 35. International Geosphere-Biosphere Programme, Stockholm.

William ER, William BM, Turner II BL. 1994. Modeling land use and land cover as part of global environmental change. Climat Ch 28: 45 64. DOI: 10.1007/BF01094100 